This is an Accepted Manuscript of a book chapter published by Routledge in [Faith-based Identity and Curriculum in

Catholic Schools] on [01 Jan 2020], available online: https://www.routledge.com/Faithbased-Identity-and-Curriculumin-

Catholic-Schools-1st-Edition/Gleeson-Goldburg/p/book/9780367193836 


\title{
Teaching for a just world: social justice and human rights perspectives across the curriculum
}

\author{
Associate Professor Nina Burridge \\ Faculty of Arts and Social Science \\ University of Technology Sydney \\ nina.burridge@uts.edu.au
}

\begin{abstract}
Education today is based on a competitive corporatized model designed for job creation and geared to a market economy. This chapter attempts to present another perspective on the role of education and the school curriculum. It focuses on a holistic interpretation of what schooling should involve in both the formal and the informal curriculum in preparing students to be active and committed global citizens who engage in critical thinking about issues related to equity, social justice and human rights in the local as well as global contexts. It explores the importance of engaging in educational activities that will contribute to building a culture of respect that is based on the underlying principles of social justice, human rights and human dignity. In doing so it briefly considers the place of human rights in the Australian curriculum and the extent to which the proposed content enables teachers to employ teaching strategies that focus on social justice and human rights.
\end{abstract}

\section{Introduction: the purposes of education in the $21^{\text {st }}$ century}

Education impacts on each of us in many ways and in so many facets of our lives. Our life trajectories are often shaped, not just by our capacity to succeed in examinations but also by the values and attitudes that we learned at school. Various studies (e.g. Hattie, 2003) illustrate how the influences of teachers, peers and the education system generally are crucial to success at school and to our understanding the world around us.

Researchers have long debated the purposes of education from the time of Socrates, to the progressive education philosophy of John Dewey of the $20^{\text {th }}$ Century, the liberationist philosophy of the 1960s in Paulo Friere's Pedagogy of the Oppressed (1968), to today's debates about the market driven education system that favours education for 'workforce development' to meet a nation's economic needs (Ball, 2012; Lingard, 2010). Many believe that the current focus on the credentialist economic model of education is misplaced insofar as education is about much more than gaining a qualification for work and teaching is much more than just getting students to pass their exams.

Teaching is more than a profession; it is a way of having an impact on people and communities. When I joined the teaching profession the slogan was 'teach and make a difference'. In my role as History teacher I came to realise that learning about world history provided me with an understanding of society, social class and how power, politics and society interact. The capacities for empathy and critical thinking are important skills when it comes to teaching about the past. They involve the ability to imagine, to see the world in a multifaceted way and to analyse the impact when wrongs are committed and rights are infringed. Empathy and critical thinking develop the capacity to put oneself in someone else's shoes and to understand their contexts, their experiences and their rights as human beings. 
The notion of teaching as a moral practice (Pring, 2001) and the teacher as an 'activist professional' (Sachs, 2000) are central to the focus in this chapter on human rights and social justice. This means viewing a teacher as a person with a moral mission to help create a better world by educating young people about issues of equity, social justice, and rights, not just in their local context but also in the wider global sphere.

Nussbaum $(2009,2010,2016)$ writes that the purpose of education is for 'human development', helping students to become educated in their fields and also critically aware, active participants in their communities and in global issues.

The goal of education for human development, is producing decent world citizens who can understand the global problems .... and who have the practical competence and the motivational incentives to do something about these problems" $(2009$, p. 6).

Education for human development competes with the more instrumentalist objectives of education. As Martha Nussbaum points out:

Education is often discussed in low-level utilitarian terms: how can we produce technically trained people who can hold onto "our" share of the global market? With the rush to profitability, values precious for the future of democracy are in danger of getting lost. The profit motive suggests to most concerned politicians that science and technology are of crucial importance. We should have no objection to good scientific and technical education. But other abilities - abilities crucial both to the health of democracy and to the creation of a decent world culture and a robust type of global citizenship - are at risk of getting lost in the competitive flurry $(2009$, p. 6).

According to Nussbaum global citizenry requires critical thinking, the capacity for Socratic dialogue, self-criticism and critical thought about one's own traditions in order to facilitate dialogue across political boundaries. It also requires the ability to understand difference, both to see oneself as a member of a heterogeneous world and to understand the history and character of diverse groups. And finally, it requires narrative imagination and empathy, the ability to be an intelligent reader of other people's stories, and to think about what the inner life of another may be like (Nussbaum, 2016).

Nussbaum's philosophy provides ambitious goals for education at a time when the curriculum is already overloaded (Australian Government, 2014) and teachers feel the pressure of having to meet many expectations in relation to their roles which often go far beyond their expertise or discipline knowledge (e.g. Polesel, Rice, Duffner, 2014). Yet it cannot be denied that teachers are in a position to influence the development of students not just as learners but as human beings, as citizens and members of a broader community.

Against that background the next section of the chapter considers the purposes of education from the perspectives of social justice and human rights. This is followed by consideration of the explicit and implicit opportunities for human rights education in various subject areas based on our empirical evidence. This naturally leads on to a discussion of the classroom applications of these findings and their implications for teacher professional learning. The relevance of our findings to Catholic schools is considered followed by some concluding remarks. 


\section{Social justice and human rights in education}

There is much that connects the concepts of social justice and human rights. Social justice is often defined as the aspiration for equity for all human beings in terms of the distribution of wealth, access to education, employment and social services. Social justice implies a sense of connection to the principles of egalitarianism and ethical behavior, as well as access to and involvement in policy development and administration. A humane society is the product of a socially just society.

A socially just society presupposes that individuals and governments understand that all humans have a right to live with dignity and have their rights respected. Peaceful, rightsbased solutions to conflict have often emerged in the aftermath of conflict such as World Wars. For example, the United Nations and its Declaration on Human Rights (1948) emerged from the chaos of the Second World War. While the United Nations has been criticized as being an impotent body for its failure to stop international crises (McGreal, 2015), it has nevertheless enacted international human rights conventions, declarations and treaties that at the very least provide a focus for human rights. Individual nations have also adopted Human Rights Acts and while Australia is one of the few democratic countries not to have introduced Human Rights legislation at the Federal level, some Australian states/territories such as Victoria and the Australian Capital Territory (ACT) have their own human rights legislation (Burridge, Chodkiewiz, Payne, Oguro, Varnham and Buchanan, 2013). In the absence of Federal legislation students should learn over the course of their schooling about civil and political rights, economic, social and cultural rights, humanitarian rights, and various group rights (workers, women, children, minority groups, refugees, Indigenous people and people with a disability).

Human rights and the rights frameworks that are embedded in national and international human rights conventions and declarations serve as moral and legal frameworks (AHRC, 2018) which are universal and inalienable (OHCHR, 2015). Educating young people about international human rights frameworks and legislation is an important way of underpinning rights and freedoms in our democratic system. Osler and Starkey emphasise the important role of education in strengthening democracy and providing young people:

...with appropriate experiences which allow them to make sense of international politics and interdependence while at the same time enabling them to feel that they can make a difference and participate in shaping our common future. $(2005$, p. 12)

As has been argued above, education is much more than what happens between the four walls of a classroom. It is also much more than assessment, measurement and international testing systems such as the Programme for International Student Assessment (PISA). It is not just about preparation for work, as emphasised by the corporate mindset of politicians and leaders of industry. It is a complex mixture of all these, but also much more. Ensuring a focus on human rights education in the school curriculum is one way to build greater emphasis on broader goals and purposes of education. 


\section{Legislative and policy frameworks}

Education about human rights in schools is shaped by international legislation and Australian policy frameworks that link back to the adoption of the Universal Declaration of Human Rights:

Education shall be directed to the full development of the human personality and to the strengthening of respect for human rights and fundamental freedoms. It shall promote understanding, tolerance and friendship among all nations, racial or religious groups, and shall further the activities of the United Nations for the maintenance of peace. (UDHR. 1948, 26.2)

Since 1948, the United Nations has urged countries to disseminate the Declaration and to educate people about its contents, as well as the subsequent UN human rights conventions, treaties and charters, which have all included a role for school education (OHCHR, 2004).

Recent developments in human rights education at the international level have been marked by the UN Decade for human rights education (1996-2004), the World Program on Human Rights Education (2005), and the publication of the UN Declaration on Human Rights Education and Training (2011) which stated that: ... all educational, training, information, awareness-raising and learning activities [are] aimed at promoting universal respect for and observance of all human rights and fundamental freedoms and thus contributing... to the prevention of human rights violations and abuses by providing persons with knowledge, skills and understanding and developing their attitudes and behaviours, to empower them to contribute to the building and promotion of a universal culture of human rights (Office of the High Commissioner for Human Rights, 2011, p. 3).

In 2010, the Australian Labor government undertook to develop both a Human Rights Framework and Action Plan in response to the National Consultation of 2009 which recommended that human rights education should be a priority in schools and government organisations in order to build a culture of rights (Commonwealth of Australia, 2009).

While the focus on human rights education is continuing at the international level and the United Nations has initiated the third phase of the world program for human rights education (2015-2019) the Australian Government has done little to promote human rights education within our education system or within public policy frameworks. Therefore, it has been left up to individual teachers, schools and educational administrators to examine the opportunities for human rights education provided by the recently introduced national Australian Curriculum and to implement programs, activities and classroom strategies that focus on building a rights-based culture in schools.

The remainder of this chapter will report on our study of human rights education in Australian primary and secondary schools up to 2012 and on the possibilities offered by the introduction of the Australian Curriculum around that time. 


\section{Explicit and Implicit teaching of human rights in the curriculum of Australian States and Territories}

This section of the chapter presents the main findings from Human Rights Education in the School Curriculum (Burridge et al, 2013). The aim of our study was to identify curriculum explicit and implicit opportunities for human rights education in the primary and secondary school curriculum in each Australian state and territory. The key research questions included whether human rights issues were addressed explicitly or implicitly, whether topics were compulsory or elective, the availability and range of sector specific initiatives, the impact of state and territory human rights legislation and other curricular learning opportunities. Our data collection methods involved roundtable discussions and interviews as well as documentary analysis of available primary and secondary school curriculum materials. The purpose of the roundtable discussions/interviews in each state and territory was to gain the perspectives of government and independent school sectors, curriculum agencies, teacher associations and the main non-government groups working on human rights issues within schools. School curriculum materials were analysed to identify the curriculum subject areas that provide opportunities for students to learn about human rights issues.

Our evidence suggests that human rights education was only addressed in a relatively narrow base of subjects. While opportunities existed for students to learn about fairness and respect, these were not presented in terms of human rights education and were at the discretion of the individual teacher. There was a widely-expressed view that the curriculum in all states and territories suffered from overcrowding "as educational policy makers tried to meet political and community-based demands for addition to the curriculum that would address an ever increasing set of issues related to safety, health and wellbeing, emergence of social media" (Burridge et al, 2013, p. 58). A recurring argument in the various roundtable discussions was that human rights education would only be taken seriously when it became mandatory, that is when ACARA and the various states and territories include human rights, as well as ethical understanding, as an explicit part of the Australian school curriculum.

The roundtable discussions and document searches threw up a discernible difference between explicit references to human rights terminology/topics in the curriculum documents and implicit references for the capacity to cover human rights issues. The overall sense emerging from the roundtables was that "participants referred to specific subjects without a clear understanding of the topics or issues addressed" (Burridge et al, 2013, p. 59).

As might be expected, the Years 11-12 subjects with the most explicit references to human rights humanities-based included History, Geography and Legal Studies years along with Politics and International Studies and Aboriginal Studies and Society. The lower secondary years curriculum provided explicit opportunities to study a diverse set of human rights issues in History, Geography, Aboriginal Studies; and Civics and Citizenship units. There was, however, no guarantee that human rights would be an essential curriculum theme even where such syllabus units were defined as mandatory.

Human rights issues were not explicitly named or addressed in any subject areas across the primary curriculum up to Year 4 while there were implicit opportunities in the Years 5 and 6 History and Geography and Civics and Citizenship syllabuses and in the English K-6 and, in some states, in the Physical Development, Health and Physical Education (PDHPE) K- 6 syllabuses. The researchers concluded the "gap in the current curriculum of an explicit focus 
on human rights education in the primary years, and particularly in early childhood education K-2" (Burridge et al, 2013, p. 60).

A summary of the main findings of our study is presented in Figure 1 in the Appendix below.

\section{Social justice, human rights in the Australian curriculum}

The Australian Curriculum and Reporting Authority (ACARA) began work on the development of the national curriculum in 2007/8 and individual learning areas were developed over a number of years, beginning with English, Mathematics, Science, and History in 2010. This complex process was undertaken in stages and the Foundation to Year $10(\mathrm{~K}-10)$ curriculum is now being implemented while Years 11 and 12 reforms are also coming on stream.

The Shape of the Australian Curriculum (ACARA 2012) identifies eight learning areas (with their respective subjects), seven General Capabilities and three Cross-Curriculum Priorities. Two of the General Capabilities are of particular importance to human rights education namely Ethical Understanding and Intercultural Understanding. ACARA (2012) defines these as follows:

Students develop ethical understanding as they identify and investigate the nature of ethical concepts, values and character traits, and understand how reasoning can assist ethical judgment. Ethical understanding involves students in building a strong personal and socially oriented ethical outlook that helps them to manage context, conflict and uncertainty, and to develop an awareness of the influence that their values and behaviour have on others. (ACARA 2012 p.17)

Students develop intercultural understanding as they learn to value their own cultures, languages and beliefs, and those of others. They come to understand how personal, group and national identities are shaped, and the variable and changing nature of culture. The capability involves students in learning about and engaging with diverse cultures in ways that recognise commonalities and differences, create connections with others and cultivate mutual respect. (ACARA 2012, p.17)

The Australian Curriculum identifies three cross-curriculum priorities to be embedded across all learning areas which are important to equip young Australians with the skills, knowledge and understanding to engage in a globalised world. These are: Aboriginal and Torres Strait Islander histories and cultures; Asia and Australia's engagement with Asia; and Sustainability. Participants in the Human Rights roundtable discussions (Burridge et al, 2013 p. 61) noted that the new emphasis on Science and Society and on Sustainability as a crosscurriculum theme provided openings for human rights to be addressed in the Science curriculum.

While there are no explicit references to social justice or human rights within the crosscurriculum priorities there are implicit understandings about culturally responsive approaches to engaging with Australia's Indigenous peoples and culture and with neighbouring countries and cultures as well as the importance of human rights and freedoms. 
Roundtable participants saw the introduction of a national curriculum subjects as providing real opportunities to embed essential learning about rights into the national agenda for all schools insofar as "publishers will be able to produce something for the whole nation that could be used. The little publications we've had state by state [on human rights] could be replaced because they're more economically viable" (Burridge et al, 2013, p. 60).

Participants expressed their disappointment however that, despite some advocacy from the Australian Human Rights Commission, "human rights education was not specifically mentioned in the overarching framework of the Australian Curriculum" (Burridge et al, 2013, p. 60). They called for the inclusion of human rights in the support documentation for the general capabilities of ethical understanding and intercultural understanding as well as all three cross-curriculum priorities.

They welcomed the inclusion of specified knowledge and understanding of Aboriginal and Torres Strait Islander cultures as an essential set of skills for accreditation in the new National Teacher Professional standards introduced by the Australian Institute for Teaching and School Leadership (AITSL) in 2013. Given the diverse nature of our student population and the multicultural nature of our classrooms today, it was also seen as important to combine multiculturalism and diversity within a general human rights approach. The overall recommendation of our report was that, "once the new national Australian Curriculum is fully developed and implemented, Australian Curriculum subjects need to be audited to determine the extent to which human rights issues have been effectively integrated into the curriculum" (Burridge et al, 2013, p. 61).

\section{Teaching about Human Rights in the classroom}

As human rights educators, teachers need to develop students' critical thinking skills so that they can evaluate evidence, make judgments about human rights issues in the community and develop active citizenship. Students must learn to understand differing perspectives, develop empathy, question what they're being told and ask whose agendas are and are not being served. This capacity can be developed through engaging with real life scenarios through simulations, gaming, debates and community action beyond the classroom.

Participants identified important prerequisites to effective implementation of any human rights issues in schools. They noted the importance of pedagogical practices i.e. how we teach was of equal importance to what we teach. Since students need constant engagement and technologies are constantly being upgraded, teachers need to be skilled in a variety of teaching and learning methods and to have an understanding of the cultural contexts in which they find themselves. Participants also expressed concerns about how the outcomes of human rights education could be assessed. Concerns were also raised about the importance of developing and distributing relevant resources and emphasized the value of a centralized repository for materials

Participants emphasised that teachers needed to model human rights in order for a culture of rights to develop and for students to actively embrace new understandings about rights and bring about transformative learning. A great deal still depends on teacher interests and commitment, as well as the kind of pedagogy and approach they used in their human rights teaching. It is individual teachers who determine the level of detail in teaching about human rights, particularly at the 'explicit' level. 
Choosing which rights to teach is a highly contested question (Cassidy et al., 2014) since political and social debate impacts variously on educators and school sectors. The existing national Australian human rights framework provides a useful starting point and the Australian Human Rights Commission (2015) has identified the following areas for investigation: civil and political rights, the right to adequate food and water, healthcare, education, a clean environment, welfare assistance; and humanitarian rights such as the rights of prisoners.

Our research found that teachers were often reluctant to approach controversial issues. It is clear from our roundtable discussions that the context of the school often determined what issues were discussed and what texts were taught and that many teachers did not want to put themselves into a position where they had to contradict a school's approach or its policies or come into conflict with the parent community or the school system they worked in. As noted by Branigan \& Ramcharan (2012), dealing with Indigenous rights/culture, women's and/or children's rights and religious freedom, as well rights pertaining to gender and sexuality, poses difficult challenges for teachers in classrooms, some of whom feared that teaching children's rights may create classroom disruption.

On the other hand, there is research which indicates that, if children are taught about rights and respect for rights, their attitudes to others become more positive and accepting (Tibbitts \& Fernekes, 2011). Similarly, a study on values education undertaken by Education Services Australia found that in schools where values were embedded in curriculum content and pedagogy, children exhibited "increased empathy, tolerance, understanding and respect; increased sharing and team work; and greater willingness to tell the truth and accept responsibility for their actions... [and] decreased playground fighting" (Education Services Australia, cited in AHRC, 2011, p 4). It was noted that, while some restorative justice programs which operate in both private and public education systems are linked to schools that have challenging discipline-based environments, other programs are linked to an improved understanding of children's rights.

It is important for schools to set parameters, to openly discuss issues and upskill teachers through targeted professional learning programs and provide them with the necessary awareness, knowledge, skills and strategies so as to effectively tackle contested issues. In this world of global connectivity, the capacity to link with schools internationally is an important aspect of human rights education. Teachers can extend their students' learning opportunities around various aspects of human rights education by building up their capacity to link with schools in other countries. The capacity to utilise social media in a safe way, to connect with corresponding schools is also a valuable way to extend such collaborations. This may also enable cultural exchanges, perhaps with the support of local and international NGOS. The Asian Education Foundation, World Vision and the United Nations Youth Association as well as many other NGOS are already using technologies to engage with and create new global interactive opportunities.

As with all curriculum innovations, strong executive leadership that supports staff and specific programs is essential to change in schools and participants commented on "the difference good distributive leadership made by taking a whole-school approach to a project" (Burridge et al, 2013, p. 62). Participants also identified the importance of the role of parents and the community in human rights education. The need to engage with parents about human rights education is particularly important in schools where parents have expressed concerns 
about the teaching of controversial issues. Useful precedents are available in anti-bullying restorative justice projects, in Play By the Rules, a national project about fair play in sport and in Fair Go Sport.

\section{Social Justice and Social Responsibility in Catholic Schools}

Our research identified specific opportunities for human rights education in the social justice and social responsibility syllabus in faith-based schools that champion these activities as part of their school ethos. Roundtable participants "applaud[ed] the efforts of the Catholic school system to work with social justice issues which of course are seen as being closely related to human rights education. More importantly, these projects are often linked with community groups, with NGOs and their own faith based lay organisations and do actively engage students in their operations' (Burridge et al, 2013, p. 61). The treatment of controversial issues can be particularly difficult in the context of faith-based schools.

A feature of the Catholic Education system is its focus on aspects of social justice and social responsibility with an emphasis on Gospel values and Catholic social teaching. Such projects are often linked with community groups, NGOs or faith-based organisations and actively engage students in their operations. One such useful resource is the Catholic Social Teaching tool kit (Caritas Australia,) designed for both primary and secondary years to promote a sense of social responsibility. The Catholic social teaching themes included in the tool kit relate well to rights and responsibilities and the importance of human dignity which could be explored in English, Human Society and its Environment (HSIE), and Personal Development, Health and Physical Education (PDHPE) subjects in both the primary and secondary years.

Beyond the mandated curriculum, many Catholic schools engage in community projects that have a social justice and/or human rights focus. These range from visiting homeless shelters, women's refuges and youth agencies to global peace-based activities as well as fundraising for specific causes such as poverty or the elimination of child labour (Burridge et al, $2013 \mathrm{p}$. 37). Catholic schools also engage in social justice activities through a number of Catholic organisations, linking students to the work of Catholic agencies such as Caritas and the St Vincent de Paul Society. Caritas Australia, the Catholic Church's international aid and development organisation, works in over 30 developing countries. Grounded in the Catholic Social Justice Teaching tradition it supports long term development programs in impoverished communities in Africa, Asia, East Timor, the Pacific, Latin America and Australian Indigenous communities.

\section{Teacher professional learning}

All the roundtables identified the crucial importance of professional learning for teachers in the implementation of a human rights education strategy and in the changing context of the new Australian national curriculum. For example, teachers felt quite vulnerable in the newly mandated areas of Indigenous rights and history. It was reported that teachers were hesitant to approach certain issues because they felt they lacked the skills to deal with them appropriately and it was suggested that education departments and schools should work with professional teacher associations to provide more targeted professional learning opportunities for teachers. This was seen as particularly important in view of the changes that the Australian curriculum would bring to schools. We found, however, that "[f]ew programs 
were available or had been offered to enable and support teachers to implement the various curriculum opportunities that were already in place" (Burridge, et al, 2013, p. 47).

Teacher associations are well placed to contribute to human rights education, and filling the gaps in teacher knowledge and expertise about human rights issues. These associations may have the capacity to support teachers through workshops, annual conferences and the application of various communication technologies.

Teacher education providers have opportunities to focus on human rights both from a philosophy of education perspective and the development of a rights-based culture in schools and classrooms. While the deconstruction of power structures within society is often attempted through the lens of Sociology of Education, not all teacher education providers undertake to develop pre-service teachers' ideas about social justice and global citizenship. Providing learning experiences with a human rights focus where communication technologies, social media and interactivity are utilised is an important consideration for teacher education institutions.

Developing schools as holistic learning communities connected with key local organisations such as NGOs who work with the homeless or women's shelters or in refugee support services enhances student learning by making it authentic and ensures that individual learning areas and subjects are not silos but linked through cross-curriculum activities. Teachers and schools should be encouraged to reach out and develop global networks to enrich the education process for their students.

\section{Conclusion}

The researchers have noted the potential opportunities provided for Human Rights Education in the curriculum along with the barriers to their realisation. While there was general support for human rights education in the roundtable discussions "there appears to be some reluctance or ambivalence among school educators and teachers about the teaching of human rights" (Burridge et al, 2013, p. 58).

The paramount reason for educating students about human rights is to create a more socially just society and to engage students in the process of becoming active global citizens who are confident and creative, who actively engage in their communities and who "take responsibility for their own actions, respect and value diversity and see themselves as contributors to a more peaceful and sustainable world" (Bradbury, 2013, p. 221).

Engaging students in activities that enable them to think critically about issues requires teachers to provide experiential and activity centered learning that involves problem solving and futuristic thinking. Such learning also involves presenting students with effective multifaceted classroom activities that involve connecting with global communities, so that they analyse and discuss the diversity of the planet in social, political and economic terms. It requires committed teachers who will assist students to investigate the challenges the world faces in times of great technological change where social media, for example, is impacting on our rights and freedoms.

The implementation of effective and worthwhile human rights programs in schools requires commitment not just from one passionate teacher, but from the leadership team in the school to enable a whole school approach to build a rights-based culture in the school. There is a real need to work with national and state-based curriculum bodies as well as the various 
school sectors to ensure that human rights, social justice and ethical behaviour, are included as an explicit part of the formal school curriculum. Further it is crucial that pre-service teachers are supported with adequate and effective teacher professional learning and access to quality resources and technologies so that they become advocates for human rights education based programs in schools. The time is now for education systems and schools to focus on building in the students of tomorrow the aspiration and capacity to fight for a socially just world that respects human rights and the dignity of all creatures.

The overall conclusion of our study was that, insofar as Australian education systems and providers place emphasis on social justice, there is nevertheless a lack of clarity and direction when it comes to human rights education. While we identified good opportunities at secondary level for the explicit treatment of human rights, there was an obvious gap at primary level. It is too early to comment on the Australian Curriculum although the absence of explicit reference to human rights education there is disconcerting. Context is everything, and the failure to incorporate human rights education across the curriculum must be seen against a background of "the lack of support by some political leaders, particularly at the national level, for the introduction of an Australian Human Rights Act" (Burridge et al, 2013, p. 58). 


\section{Figure 1 Explicit and implicit opportunities for treatment of human rights across the curriculum}

Curricular opportunities

An analysis of the opportunities for human rights education in the school curriculum shows that:

- The Senior Years 11-12 provide the most explicit and implicit learning opportunities to study topics that are clearly related to human rights issues.

- among these opportunities there are a mix of mandatory and elective topics.

- Only a small number and proportion of students are likely to study human rights issues to any significant extent across their school years

- the study of human rights issues takes place without any clear overall definition of rights and mostly without any overarching context or link back to UN declarations, treaties, conventions or recent Australian rights legislation.

In the Senior Secondary Years:

- the main explicit opportunities found as a result of this study are in History, Geography, Legal Studies subjects and in Civics and Citizenship units of study.

- a number of subjects with small enrolments and not widely available also provide explicit opportunities for teaching about human rights. These subjects are: Politics; Society and Culture; Aboriginal Studies; Women's Studies; and Studies in Religion.

- implicit opportunities were found in the subjects English; Science; Economics \& Business.

- only a few subjects, specific to a few states and territories namely History, Australian \& Global Politics, Australian \& International Politics, and Aboriginal Studies specifically mentioned any UN human rights declarations, treaties or conventions or Australian rights legislation.

In the Junior Secondary Years:

- across the Secondary Years 7 to 10, it was mostly the Year 9 and 10 curriculum that offered the main explicit opportunities for human rights teaching --- in History, Geography, Aboriginal Studies subjects and Civics and Citizenship units.

- implicit opportunities occurred in English, Science, and Economics.

In the Primary Years:

- human rights issues did not appear to be explicitly mentioned. Implicit opportunities were found mostly in the Human Society and its Environment (HSIE) or its equivalent Learning Area

- the subjects included History; Geography, English, Physical Development Health \& Physical Education (PDHPE); and Civics and Citizenship units.

(Burridge et al, 2013, p. 65)

\section{References}

Abdi, A.A. (2017). The rhetorical constructions of global citizenship and the location of youth: A critical analysis, International Journal of Development Education and Global Learning, 8(2), 37-52. doi.org/10.18546/IJDEGL.8.2.04.

Australian Curriculum and Reporting Authority [ACARA] (2013a). General capabilities. Retrieved from http://www.acara.edu.au/curriculum/general_capabilities.html.

Australian Curriculum and Reporting Authority [ACARA] (2013b). Civics and Citizenship. Retrieved from http://www.acara.edu.au/curriculum_1/learning_areas/humanities_and_social_sciences/civics_and_citizensh ip.html.

Australian Curriculum and Reporting Authority [ACARA] (2013). Cross Curriculum Priorities. Retrieved from http://www.acara.edu.au/curriculum/cross_curriculum_priorities.html.

Australian Human Rights Commission [AHRC] (2014). Human rights examples for the Australian Curriculum. Sydney: AHRC. Retrieved from https://www.humanrights.gov.au/our-work/education/ publications/humanrights-examples-australian-curriculum. 
Andreotti, V. (2011). The political economy of global citizenship education, Globalisation, Societies and Education, 9:3-4, 307-310, DOI: 10.1080/14767724.2011.602292.

Barrow, E. (2017). No Global Citizenship? Re-envisioning Global Citizenship Education in Times of Growing Nationalism. The High School Journal, 100(3), 2017, pp. 163-165. doi:10.1353/hsj.2017.0005

Bourn, D. (2015). A pedagogy of development education: Lessons for a more critical global education, In B. M. Maguth \& J. Hilburn (Eds) The State of Global Education: Learning with the world and its people. (pp.1326). New York: Routledge.

Bradbery, D. (2013). Bridges to global citizenship: Ecologically sustainable futures through children's literature. Australian Journal of Environmental Education, 29(2), 221-237. DOI: 10.1017/aee.2014.7.

Burridge (2014). Education for a just and inclusive society. Retrieved from http://www.lowsesschools.nsw.edu.au/Portals/0/upload/resfile/Education_for_a just and inclusive society 2011.pdf

Burridge, N., Buchanan, J. \& Chodkiewicz, A. (2014). Human rights and history education: An Australian study. The Australian Journal of Teacher Education, 39(3). 17-36.

Burridge, N., Chodkiewicz, A., Payne, A., Oguro, S., Varnham S. \& Buchanan, J. (2013). Human rights education in the school curriculum. Report compiled for the Attorney General's Department. Sydney: University of Technology Sydney.

Caritas Australia, Educating for a Just World. Online, retrieved from https://www.caritas.org.au/learn/schools

Cassidy, C., Brunner, R., \& Webster, E. (2014). Teaching human rights? All hell will break loose! Education, Citizenship and Social Justice, 9(1), 19-33. doi:10.1177/1746197913475768

Commonwealth of Australia (2012) National Human Rights Action Plan. Retrieved from https://www.ag.gov.au/.../NationalHumanRightsActionPlan/ National\%20Human\%20Rights\%20Action\%20Plan.doc

Commonwealth of Australia (2011) Human Rights and Public Scrutiny Act Retrieved from https://www.ag.gov.au/RightsAndProtections/HumanRights/Human-rights-scrutiny/Pages/default.aspx

Commonwealth of Australia (2010) Australian Human Rights Framework. Retrieved from https://www.ag.gov.au/Consultations/Documents/Publicsubmissionsonthedraftbaselinestudy/AustraliasHum anRightsFramework.pdf.

Dewey, J (1897) My Pedagogic Creed. The School Journal, Vol. LIV, No. 3

Ellis, M. (2016). The critical global educator: global citizenship education as sustainable development. Abingdon, Oxon; New York: Routledge.

Education Services Australia (ESA). (2011). Defining Global Citizenship. Retrieved from http: www.civicsandcitizenship.edu.au/verve/_resources/S101_Defining_Global_Citizenship_ed.pdf.

Education Services Australia (ESA) (2011a). Global Perspectives: A framework for global education in Australian schools. Carlton South, Vic: Education Services Australia.

Freire, P. (1968) Pedagogy of the Oppressed. New York, Seabury Press.

Global Education First Initiative (GEFI) (2012). Priority 3. Global citizenship. United Nations SecretaryGeneral. Retrieved from http://www.globaleducationfirst.org/220.htm.

Guo, L. (2014). Preparing teachers to educate for $21^{\text {st }}$ Century Global Citizenship: Envisioning and enacting, Journal of Global Citizenship \& Equity Education, 4(1), 1-23. 
Hahn, C. L. (2016). Pedagogy in citizenship education research: A comparative perspective. Citizenship Teaching \& Learning, 11(2), 121- 137. doi: 10.1386/ctl.11.2.121_1.

Hahn, C. (2012). The Citizenship Teacher and Teaching Controversial Issues: A Comparative Perspective, In J. Brown, H. Ross \& P. Munn (Eds). Democratic citizenship in schools: teaching controversial issues, traditions and accountability. (pp.48-59). Edinburgh: Dunedin Academic Press.

Hattie, J.A.C. (2003) Teachers make a difference: What is the research evidence? Paper presented at the Building Teacher Quality: What does the research tell us ACER Research Conference, Melbourne, Australia. Retrieved from http://research.acer.edu.au/research_conference_2003/4/

Human Rights Education Associates (HREA, 2014). The role of national human rights institutions in advancing human rights education. Retrieved from http://www.hrea.org/index.php?base_id=1723\&language_id=1

Leighton, R. (2014). Citizenship teachers - different types, different needs, Citizenship Teaching \& Learning, 9(1), 85-98. doi: 10.1386/ctl.9.1.85_1.

McGreal, C. (2015) 70 years and half a trillion dollar later: what has the United Nations achieved? The Guardian, retrieved from https://www.theguardian.com/world/2015/sep/07/what-has-the-un-achieved$\underline{\text { united-nations }}$

Merryfield, M.M. (2015). Developing global consciousness, In S. Totten (Ed) The importance of teaching social issues. (pp.202-207). New York: Routledge.

Nussbaum, M. (2016) The Struggle Within: Education and Human Development. ABC Religion and Ethics, retrieved from http://www.abc.net.au/religion/the-struggle-within-education-and-humandevelopment/10097290 accessed Nov 2017).

Nussbaum, M. (2011). Creating capabilities. Cambridge, MASS: Cambridge University Press.

Nussbaum, M. (2010). Not for profit. Princeton, NJ: Princeton University Press.

Nussbaum, M. (2009). Education for profit, education for freedom. Liberal Education, 95(3), 6-13.

National Human Rights Consultation Committee (NHRCC) (2009) National Human Rights Consultation Committee Report. Retrieved from https://www.ag.gov.au/RightsAndProtections/HumanRights/TreatyBodyReporting/Documents/NHRCRepor t.pdf.

Office of High Commissioner for Human Rights (OHCHR) (2015) Vienna Declaration and Programme of Action. Retrieved from http://www.ohchr.org/EN/ProfessionalInterest/Pages/Vienna.aspx.

OHCHR (2015a). United Nations Decade for Human Rights Education (1995-2004). Retrieved from http://www.ohchr.org/EN/Issues/Education/Training/Pages/Decade.aspx

OHCHR (2015b). World Programme for Human Rights Education (2005-ongoing). Retrieved from http://www.ohchr.org/EN/Issues/Education/Training/Pages/Programme.aspx

OHCHR (2018) What are Human Rights? Retrieved from https://www.ohchr.org/en/issues/pages/whatarehumanrights.aspx

Osler, A. (2010). Teacher interpretations of citizenship education: national identity, cosmopolitan ideals, and political realities, Journal of Curriculum Studies, 43(1), 1-24, DOI:10.1080/00220272.2010.503245.

Polesel, J., Rice, S., Dulfer, N. (2014) The impact of high-stakes testing on curriculum and pedagogy: a teacher perspective from Australia, Journal of Education Policy, 29:5, 640-657, DOI: 10.1080/02680939.2013.865082

Professional Teachers Council (PTC NSW) (2016). Global perspectives: A framework for the development of active global citizenship in NSW schools. Retrieved from: http://www.ptc.nsw.edu.au/gepnsw/ frameworkfor-global-education. 
Robertson, G. (2009). The public good and the education of children. Keynote address, National Public Education Forum, 2009. Retrieved from http://www.aeufederal.org.au/Publications/2009/NPEF/GRobertson.pdf.

Tibbits, F. and Kirchschlaeger, P. (2010). Perspectives of research on human rights education, Journal of Human Rights Education, 2(1), September.

UN General Assembly (2014). Plan of action for the Third Phase (2015-2019) of the World Programme for Human Rights Education. Retrieved from http://www.ohchr.org/EN/Issues/Education/Training/WPHRE/ThirdPhase/Pages/ResolutionsReports.aspx

UNESCO (2014). Global Citizenship Education: Preparing learners for the challenges of the $21^{\text {st }}$ century. Paris: United Nations Educational, Scientific and Cultural Organization. Retrieved from http://www.unesco.org/new/en/global-citizenship-education.

UN General Assembly (2012) United Nations Declaration on Human Rights Education and Training. Retrieved from http://daccess-ddsny.un.org/doc/UNDOC/GEN/N11/467/04/PDF/N1146704.pdf?OpenElement.

World Vision Australia (2014). School resources. Retrieved from http://www.worldvision.com.au/Resources/SchoolResources/Default.aspx. 